\title{
Exon 7 splicing variant of estrogen receptor $\alpha$ is associated with pathological invasiveness in smoking-independent lung adenocarcinoma
}

\author{
AYUMI SUZUKI ${ }^{1}$, KATSUHIRO OKUDA ${ }^{1}$, MOTOKI YANO ${ }^{1}$, RISA ODA ${ }^{1}$, TADASHI SAKANE ${ }^{1}$, \\ OSAMU KAWANO ${ }^{1}$, HIROSHI HANEDA ${ }^{1}$, SATORU MORIYAMA ${ }^{1}$, \\ MAKOTO NAKANISHI $^{2}$ and RYOICHI NAKANISHI ${ }^{1}$
}

\author{
${ }^{1}$ Department of Oncology, Immunology and Surgery, Nagoya City University Graduate School of Medical Sciences, \\ Mizuho, Nagoya 467-8601; ${ }^{2}$ Division of Cancer Cell Biology, Department of Cancer Biology, \\ The Institute of Medical Science, The University of Tokyo, Minato, Tokyo 108-8639, Japan
}

Received August 28, 2016; Accepted February 27, 2017

DOI: $10.3892 / \mathrm{ol} .2017 .6216$

\begin{abstract}
Patients with smoking-independent lung cancer mainly consist of females, yet the molecular background of this epidemiological feature, other than epidermal growth factor receptor (EGFR) mutation, remains unclear. Several studies have revealed the association between female hormone-associated factors and the prognosis of lung cancer, however the data remain inconsistent. The present study focused on the expression of estrogen receptor (ER) $\alpha$ in order to elucidate this association in smoking-independent lung cancer. Immunohistochemistry staining (IHC) of aromatase, ER $\alpha$ and $E R \beta$ was performed against formalin-treated tissues from 38 patients who had never-smoked who underwent complete surgical resection between 2012 and 2013. Among them, adequate RNA of the tumor and adjacent normal lung cancer was extracted from 31 matching deep frozen samples. Considering the IHC results, reverse transcription-quantitative polymerase chain reaction ( $\mathrm{RT}-\mathrm{qPCR}$ ) was performed to measure the expression level of 2 different exons of $\mathrm{ER} \alpha$, exon 6 and exon 7, which are part of the ligand binding domain of ER $\alpha$, using the Taqman gene expression assay. Extra-nuclear expression of ER $\alpha$ using IHC demonstrated a statistically significant association with pathological invasiveness. RT-qPCR results exhibited a decreased expression of ER $\alpha$ exon 7 in invasive tumor tissues, compared with their adjacent normal tissues. This is consistent with the findings of previous in vitro studies indicating that extra-nuclear ER $\alpha$ were exon 7 splicing
\end{abstract}

Correspondence to: Dr Katsuhiro Okuda, Department of Oncology, Immunology and Surgery, Nagoya City University Graduate School of Medical Sciences, 1 Kawasumi, Mizuho, Nagoya 467-8601, Japan

E-mail: kokuda@med.nagoya-cu.ac.jp

Key words: lung adenocarcinoma, non-smoker, estrogen receptor, splicing variant, invasiveness variants. No difference was observed in ER $\alpha$ exon 7 expression between normal and tumor tissues in non-invasive lung cancer tissues. When considering the EGFR mutation status, EGFR wild-type lung cancers exhibited decreased ER $\alpha$ exon 7 expression levels compared with EGFR mutated lung cancers. Extra-nuclear expression of ER $\alpha$, which may represent exon 7 splicing variants of $E R \alpha$, showed statistical association with pathological invasiveness in smoking-independent lung cancer. The post-translational splicing mechanism of ER $\alpha$ may be involved in the acquired invasiveness of smoking independent lung cancer.

\section{Introduction}

Lung cancer has the highest mortality rate worldwide. Although smoking has been established as the main cause of lung cancer (1), smoking prevalence has decreased on a global level (2). By contrast, the proportion of non-smokers among lung cancer patients have been increasing through the decades (3). Smoking-independent lung cancer has been considered as a distinct disease from lung cancer observed in smokers (4). Therefore, it is important to understand the mechanisms behind the carcinogenesis of patients with smoking-independent lung cancer in order to treat lung cancer in the next generation.

Epidermal growth factor receptor (EGFR) gene mutations are known as the main driver for oncogenic mutations in smoking-independent lung cancer (5). A total of $>50 \%$ of lung cancer patients in Asian countries harbor EGFR mutations (6), and these patients benefit from treatment with EGFR tyrosine kinase inhibitors (EGFR-TKIs).

The main EGFR mutations implicated in lung cancer are deletions in exon 19 and a point mutation occurring at codon 858 (L858R) located at exon 21 (6). These two mutations strongly predict the efficacy of EGFR tyrosine kinase inhibitors (EGFR-TKIs), with response rates $>70 \%$ (5). The activating mutations of EGFR lead to receptor dimerization and cause the activation of signaling pathways. The main EGFR signaling pathways that mediate cancer development and progression 
identified include the phosphatidylinositol 3-kinase signaling pathway where activation leads to Akt activation and suppression of apoptosis. Another signaling pathway is via the proteins growth factor receptor-bound protein 2 and Sos, which leads to the activation of $\mathrm{p} 21^{\text {ras }}$ and cell cycle progression. Activation of phospholipase C- $\gamma 1$ phosphorylation leads to PIP2-induced actin reorganization. EGFR-TKIs that target the receptor catalytic domain of EGFR suppress the activation of signaling pathways caused by EGFR dimerization (7). However, even when other mutated oncogenic driver populations, including activated anaplastic lymphoma kinase, are considered, the remaining population without oncogenic driver mutations require optimal therapy (5).

Several studies have focused on hormonal receptors due to patients with smoking-independent lung cancers being mainly female (3,8-21). Estrogen exposure measured by an indirect method could only demonstrate a weak association between female hormone-associated factors and lung cancer (22). Intratumoral estrogen expression has been demonstrated to increase tumor proliferation (10) and worse prognosis (8). However the association between prognosis outcomes and expression of receptors stimulated by increased intratumoral estrogen remain inconsistent $(11,14,21,23)$. The present study investigates the expression of female hormone-associated factors in attempt to elucidate this epidemiological feature in the non-smoking population.

\section{Materials and methods}

Patients and specimens. Paraffin-embedded specimens and frozen specimens were obtained from 38 patients who had never-smoked, who underwent complete resection for primary lung cancer between January 2012 and December 2013 at Nagoya City University Hospital (Nagoya, Japan). Patient characteristics are summarized in Table I. Lung cancer staging was determined according to the seventh edition of the TNM classification of the lung and pleural tumors (24). The pathological diagnosis was made according to the 2011 edition of International Multidisciplinary Classification of Lung Adenocarcinoma by the International Association for the Study of Lung Cancer/American Thoracic Society/European Respiratory Society (IASLC/ATS/ERS) (25). Pathological invasiveness was determined according to the IASLC/ATS/ERS definition. All frozen tumor samples were immediately frozen subsequent to surgical resection and stored at $-80^{\circ} \mathrm{C}$ until assayed. The present study was approved by the ethics committee of Nagoya City University Graduate School of Medicine (Nagoya, Japan). Written consent was obtained from all patients prior to surgery.

Immunohistochemistry (IHC). Sections of $4 \mu \mathrm{m}$ were sliced from paraffin blocks of samples from the patients specified in Table I. The slides were treated twice with xylene (Wako Pure Chemical Industries, Ltd., Osaka, Japan) for $10 \mathrm{~min}$, and subsequently dehydrated twice in $100-70 \%$ ethanol (Wako Pure Chemical Industries, Ltd.) for $5 \mathrm{~min}$ at each concentration, respectively. Following thorough washing with running water, antigen retrieval was performed using $10 \mathrm{mM}$ sodium citrate buffer adjusted to $\mathrm{pH}$ 6.0. Heating procedures for antigen retrieval and blocking of the endogenous peroxidase differed according to the antibodies. Paraffin slides for ER $\alpha$ and ER $\beta$ antibodies were autoclaved for $15 \mathrm{~min}$ at $120^{\circ} \mathrm{C}$ and endogenous peroxidase was blocked using methanol (Wako Pure Chemical Industries, Ltd.) with $0.3 \% \mathrm{H}_{2} \mathrm{O}_{2}$ (Wako Pure Chemical Industries, Ltd.) for $30 \mathrm{~min}$ at room temperature. Paraffin slides for aromatase (Cyp19) were heated by microwave oven $(500 \mathrm{~W})$ for $10 \mathrm{~min}$ at $100^{\circ} \mathrm{C}$, and endogenous peroxidase was blocked with methanol (Wako Pure Chemical Industries, Ltd.) with 3\% $\mathrm{H}_{2} \mathrm{O}_{2}$ (Wako Pure Chemical Industries, Ltd.). Non-specific antigens were blocked with Block Ace solution, diluted according to manufacturer's instructions (DS Pharma Biomedical Co., Ltd., Osaka, Japan) for $10 \mathrm{~min}$ at room temperature with all slides. Primary antibodies used were as follows: Cyp19 (C16; dilution, 1:50; cat. no. sc14245; Santa Cruz Biotechnology, Inc., Dallas, TX, USA); ER $\alpha$ (HC-20; dilution, 1:50; cat. no. sc-543; Santa Cruz Biotechnology, Inc.); and ER $\alpha$ (H-150; dilution, 1:10; cat. no. sc-8974; Santa Cruz Biotechnology, Inc.). All slides were incubated with the primary antibodies overnight at $4^{\circ} \mathrm{C}$. EnVision kit (Dako; Agilent Technologies, Inc., Santa Clara, CA, USA) and 3,3'-diaminobenzidine (DAB) substrate (Merck KGaA, Darmstadt, Germany) were used to visualize ER $\alpha$ and $\beta$ according to the manufacture's instructions. Histofine kit (Nichirei BioSciences, Inc., Tokyo, Japan) and DAB substrate (Merck KGaA) were used to visualize Cyp19 according to the manufacture's instructions. Slides were treated with $\mathrm{DAB}$ solution for $10 \mathrm{~min}$ at room temperature and immediately washed under running water for $10 \mathrm{~min}$. Chromogenic counterstains were performed using Mayer's hematoxylin solution (Wako Pure Chemical Industries, Ltd.) for $30 \mathrm{sec}$ and subsequently washed thoroughly under running water for 10 min. Following dehydration in $100 \%$ ethanol (Wako Pure Chemical Industries, Ltd.) for 4 times, the coverslips were placed using Malinol (MUTO PURE CHEMICALS Co., Ltd., Tokyo, Japan). Washing was performed three times using phosphate-buffered saline between procedures with a duration of $5 \mathrm{~min}$ for each step. Images were captured using EVOS ${ }^{\circledR}$ XL (Thermo Fisher Scientific, Inc., Waltham, MA, USA) with the objective scale set at $\times 40$. Positive staining of the tumor was determined as dense staining compared with the stromal staining in $>10 \%$ of the tumor cells. Quantification was performed manually.

$R N A$ extraction and reverse transcription-quantitative polymerase chain reaction ( $R T-q P C R)$. Total RNA was extracted from tumor tissues and adjacent normal lung tissues using an ISOGEN RNA extracting kit (Nippon Gene Co., Ltd., Tokyo, Japan) according to the manufacturer's protocol. Complimentary (c)DNA was synthesized using ReverTraAce qPCR RT MasterMix with gDNA remover (Toyobo Co., Ltd., Osaka, Japan) according to the manufacturer's protocol, and DNase was used. RNA was denaturized by incubation at $65^{\circ} \mathrm{C}$ for $5 \mathrm{~min}$. DNase removal was performed at $37^{\circ} \mathrm{C}$ for $5 \mathrm{~min}$. Reverse transcription was performed by incubating at $37^{\circ} \mathrm{C}$ for $15 \mathrm{~min}, 50^{\circ} \mathrm{C}$ for $5 \mathrm{~min}$ and $98^{\circ} \mathrm{C}$ for $5 \mathrm{~min}$, respectively. A total of $50 \mathrm{ng}$ RNA was used for each RT-qPCR reaction. RT-qPCR amplification was performed using the Applied Biosystems 7500 Fast Real-Time PCR System (Thermo Fisher Scientific, Inc.). The thermocycling conditions were set up as follows: denaturation for $20 \mathrm{sec}$ at $95^{\circ} \mathrm{C}$, 40 cycles of annealing and extension for $3 \mathrm{sec}$ at $95^{\circ} \mathrm{C}$ and 
Table I. Clinicopathological characteristics of 38 patients with lung adenocarcinoma with no smoking history.

\begin{tabular}{|c|c|}
\hline Variable & Number \\
\hline \multicolumn{2}{|l|}{ Age, years } \\
\hline Range & $43-89$ \\
\hline Average & $68.7 \pm 9.1$ \\
\hline Median & 71 \\
\hline \multicolumn{2}{|l|}{ Sex } \\
\hline Male/Female & $7 / 31$ \\
\hline \multicolumn{2}{|l|}{ BMI } \\
\hline Average & $23.1 \pm 2.8$ \\
\hline \multicolumn{2}{|l|}{ Invasiveness } \\
\hline Non-invasive/Invasive & $17 / 21$ \\
\hline \multicolumn{2}{|l|}{ Grade } \\
\hline $\mathrm{G} 1 / \mathrm{G} 2 / \mathrm{G} 3$ & $20 / 14 / 4$ \\
\hline \multicolumn{2}{|l|}{ pT } \\
\hline T1/T2/T3/T4 & $25 / 10 / 2 / 1$ \\
\hline \multicolumn{2}{|l|}{$\mathrm{pN}$} \\
\hline N0/N1/N2/Nx & $32 / 2 / 3 / 1$ \\
\hline \multicolumn{2}{|l|}{ pStage } \\
\hline I/II/III & $31 / 2 / 5$ \\
\hline \multicolumn{2}{|l|}{ EGFR } \\
\hline Wild type/Mutated & $23 / 15$ \\
\hline \multicolumn{2}{|l|}{ ALK } \\
\hline Negative/Positive/N/A & $20 / 3 / 15$ \\
\hline
\end{tabular}

BMI, body mass index; pT, tumor size; $\mathrm{pN}$, number of lymph nodes involved; EGFR, epidermal growth factor receptor; ALK, anaplastic lymphoma kinase; N/A, not applicable.

$30 \mathrm{sec}$ at $60^{\circ} \mathrm{C}$. The Taqman $^{\circledR}$ gene expression assay (Applied Biosystems; Thermo Fisher Scientific, Inc.) for aromatase (Hs00903413_m1), ER $\alpha$ exon 6 (Hs00174860_m1), ER $\alpha$ exon 7 (Custom Taqman expressing assay AI70NU8; forward primer, 5'-GAGCTGGTTCACATGATCAACTG-3', Reverse primer: 5'-AGAAGGTGGACCTGATCATGGA-3'; fluorescent probe, 5'-CAAAGCCTGGCACCCTC-3') was used, and $\beta$-actin (Hs99999903-m1) was used as an internal control. cDNA synthesized from MCF7 cell culture mRNA were obtained from Dr. Tatsuya Toyama (Department of Breast Surgery, Nagoya City University Graduate School of Medical Sciences, Nagoya, Japan) and used as a reference for the $2^{-\Delta \Delta \mathrm{Cq}}$ method to evaluate the expression of each target allele (26). A single replicate was performed for each sample per probe due to the scarce resource of the frozen specimens.

Statistical analysis. All statistical analysis was performed using JMP statistical software ver.12.0.1 (SAS Institute, Inc., Cary, NC, USA). The significance of extra-nuclear ER $\alpha$ staining was analyzed using the $\chi^{2}$ test. Quantitative comparisons were analyzed using the median test. The difference between normal tissues and tumor tissues was analyzed using

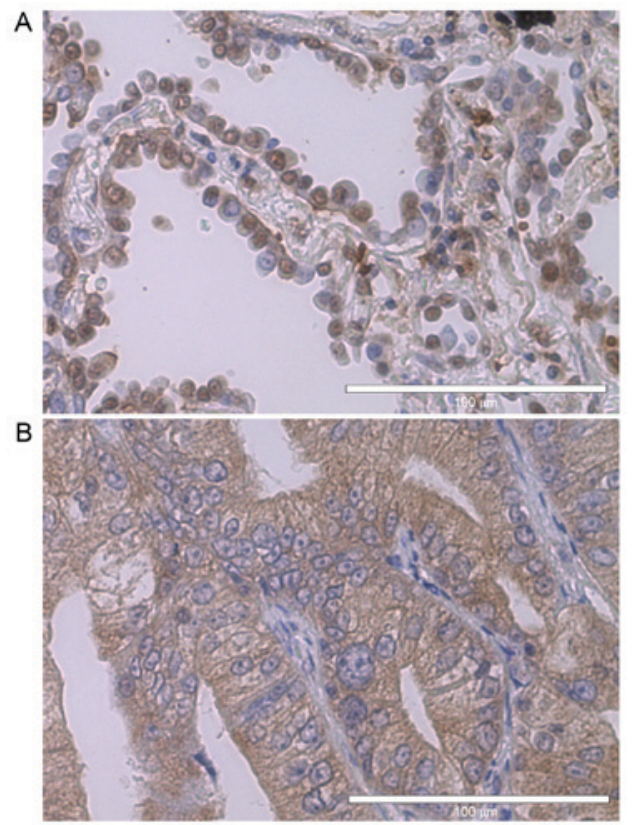

Figure 1. Immunohistochemistry staining of ER $\alpha$. All images were captured using the EVOS system. (A) Nuclear ER $\alpha$ positive tissues in high power field. (B) Extra-nuclear ER $\alpha$ positive tissues in high power field. Scale bar, $100 \mu \mathrm{m}$; magnification, $\mathrm{x} 40$. ER $\alpha$, estrogen receptor $\alpha$.

Wilcoxon's matched-pair signed rank test. $\mathrm{P}<0.05$ was considered to indicate a statistically significant difference.

\section{Results}

Extra-nuclear ERa staining is associated with pathological invasiveness of tumors. IHC staining was performed for ER $\alpha$, $\operatorname{ER} \beta$ and aromatase, which is the enzyme controlling the levels of estradiol.

ERs are known as nuclear receptors (Fig. 1A), yet notably, extra-nuclear expression of estrogen receptors was observed frequently (Fig. 1B). Taking this into consideration, the nuclear expression and extra-nuclear expression of ERs were analyzed individually. Cytosolic aromatase was expressed in $32 \%$, nuclear ER $\alpha$ in $21 \%$, extra-nuclear ER $\alpha$ in 55\%, nuclear ER $\beta$ in $92 \%$ and extra-nuclear ER $\beta$ in $47 \%$ of the tumors. Sex and body-mass-index exhibited no correlation with any of the female hormone-associated factors.

Extra-nuclear ER $\alpha$ expression was significantly associated with pathological invasiveness $(\mathrm{P}<0.001)$, lymph node metastasis $(\mathrm{P}=0.04)$ and pathological stage $(\mathrm{P}=0.01)$ (Table II). Although it was also observed that the positive expression of extra-nuclear ER $\beta$ was associated with pathological invasiveness ( $\mathrm{P}=0.05$; data not shown), no association between lymph node metastasis or pathological stage was observed. Nuclear ER $\alpha$ expression, nuclear ER $\beta$ expression and aromatase expression were not associated with any of the variables considered. These IHC data led the present study to focus on the extra-nuclear expression of ER $\alpha$.

ERa exon 7 expression was lower in more invasive tumors. A previous study indicated that ER $\alpha$ antibodies used in the present study may recognize the spicing variant of exon 7 of $\mathrm{ER} \alpha$ (27). As a wide range of splicing variants are known to be 
Table II. Clinicopathological characteristics.

Extra-nuclear ER- $\alpha$ by IHC

\begin{tabular}{lrrc} 
Variable & Negative & Positive & $\chi^{2}$ (P-value) \\
\cline { 2 - 3 } Sex & & & 0.62 \\
Male & 14 & 17 & \\
Female & 3 & 4 & 0.10 \\
BMI & & & \\
$\leq 22.5$ & 3 & 9 & \\
$>22.5$ & 14 & 12 & \\
Invasiveness & & & \\
Non-invasive & 14 & 3 & \\
Invasive & & & \\
pT & 3 & 18 & 0.06 \\
T1 & 15 & 10 & \\
T2 & 2 & 8 & \\
T3 & 0 & 2 & \\
T4 & 0 & 1 & 0.04 \\
pN & & & \\
N0 & 17 & 15 & 0.01 \\
N1-2 & 0 & 5 & \\
pStage & & & \\
I & 17 & 14 & \\
II-III & 0 & 7 & \\
EGFR & 12 & 11 & \\
Wild-type & 5 & 10 & \\
Mutated & & & \\
\hline
\end{tabular}

ER, estrogen receptor; IHC, immunohistochemistry; BMI, body mass index; pT, tumor size; $\mathrm{pN}$, number of lymph nodes involved; EGFR, epidermal growth factor receptor.

expressed in normal lung tissues and lung cancer tissues (28), direct sequencing was not adequate to assess the expression of a specific splicing variant. Therefore, a RT-qPCR system was used in an attempt to confirm the expression of this splicing variant.

Taqman probes for exon 6 and exon 7, each were prepared. Of the 38 samples used in IHC, adequate RNA was retrieved from 31, which were used in this experiment. The excluded RNA samples from 7 patients exhibited too low a concentration to assess. The $2^{-\Delta \Delta \mathrm{Cq}}$ method was used to assess the expression of each exon, using $\beta$-actin as the housekeeping gene and MCF7 cDNA as a reference sample.

No statistically significant difference in the expression of exon 6 between extra-nuclear ER $\alpha$ negative tumor samples and extra-nuclear ER $\alpha$ positive samples was observed (Fig. 2A). However, with expression of exon 7, extra-nuclear ER $\alpha$ positive samples exhibited significantly reduced expression levels compared with $\mathrm{ER} \alpha$ negative samples ( $\mathrm{P}=0.02$; Fig. 2B). Thus, these data demonstrating a lower expression of exon 7 but not exon 6 , which indicates the splicing of exon 7, is associated with extra-nuclear ER $\alpha$ by IHC.
Extra-nuclear ER $\alpha$ by IHC revealed a significant association with pathological invasiveness. Whether the lower expression of exon 7 by RT-qPCR, which indicates the splicing of exon 7 , demonstrates an association with pathological invasiveness was also investigated. In patients with non-invasive lung cancer, the expression level of exon 7 did not differ between tumor tissues and their adjacent normal tissues (Fig. 3A). However, in patients with invasive lung cancer, the exon 7 expression level was significantly lower in tumor tissues compared with the adjacent normal tissue (Fig. 3B). The median expression level of exon 7 in normal tissues did not differ between patients with non-invasive lung cancer and patients with invasive lung cancer (Fig. 3C), whereas it was significantly reduced in tumor tissues from patients with invasive lung cancer (Fig. 3D). The median expression of exon 6 did not differ between patients with non-invasive lung cancer and patients with invasive lung cancer in tumor tissues and their adjacent normal lung tissues. These results indicate invasive lung cancer tumor tissues are more likely to express ER $\alpha$ without exon 7 compared with non-invasive tissues.

All tumor tissues from male patients demonstrated a lower exon 7 expression level, yet they were all patients with invasive lung cancer and therefore the present study is not able to discuss whether this characteristic is due to sex or pathological invasiveness. EGFR wild-type tumors tended to exhibit low expression of exon 7, but this was not statistically significant (Fig. 4A-D). The EGFR mutation status demonstrated no association with the exon 7 expression level.

\section{Discussion}

The number of studies focusing on smoking-independent lung cancer has increased since EGFR mutation was identified as an oncogenic driver mutation. It is now common knowledge that women are more likely to be affected by lung cancer compared with men in the non-smoking population (5). This evidence has led the present study to investigate the association between female hormone-associated factors and lung cancer.

Although there is only weak evidence that estrogen exposure to lung tissue induces lung cancer in clinical practice (22), several studies have demonstrated that intra-tumor aromatase expression $(8,10,15,16,18,21)$ exhibits an association with poorer prognoses. The present study did not indicate statistically significant associations between aromatase expression and pathological invasiveness. As the antibodies mentioned in previous studies, which demonstrated an association between aromatase expression and poorer prognosis by $\operatorname{IHC}(15,21)$ were unavailable, human placenta tissues were used as a positive control to test the antibodies used in the present study. Sc14245 demonstrated good positive staining against human placenta, however the positive detection rate, which was $32 \%$, was much lower compared with the previous studies $(15,21)$. By contrast, the study by Mah et al (16) used the same antibody as the present study, and their positive detection rates for non-smoking women with lung cancer was $42 \%$, which was similar to the detection rate of the present study. Therefore, the authors suggest that the antibody selection for aromatase requires additional consideration. The association between aromatase expression and smoking status also requires 
A

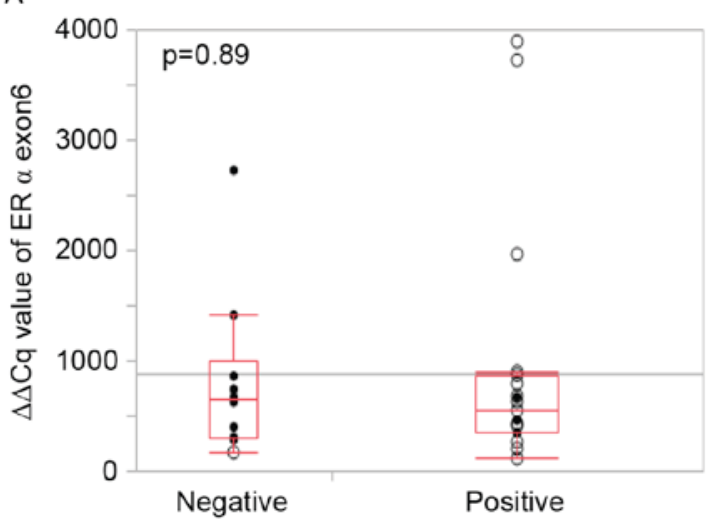

B

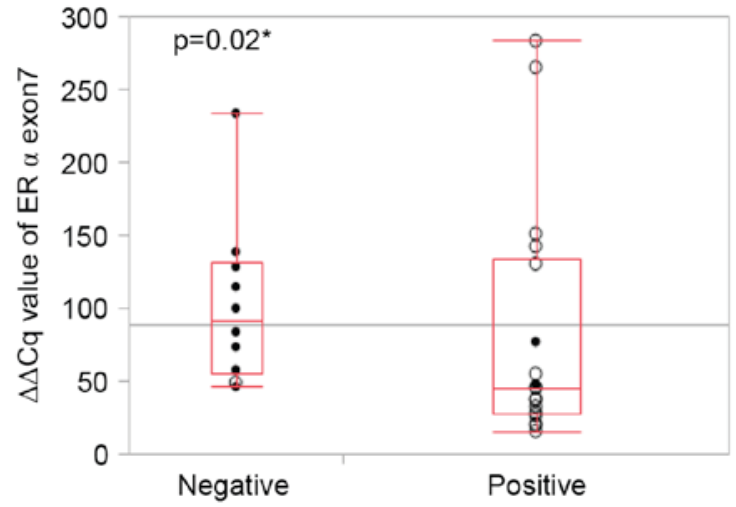

Figure 2. Association between extra-nuclear ER $\alpha$ expression and expression of exon 6 and 7 of ER $\alpha$. (A) Box plot comparing ER $\alpha$ exon 6 expression levels of tumor tissues considering extra-nuclear ER $\alpha$ status by IHC. (B) Box plot comparing ER $\alpha$ exon 7 expression levels of tumor tissues considering extra-nuclear ER $\alpha$ status by IHC. ER $\alpha$, estrogen receptor $\alpha$; IHC, immunohistochemistry staining. Black circles represent pathologically non-invasive lung cancer, and white circles represent pathologically invasive lung cancer. ${ }^{*} \mathrm{P}<0.05$. IHC, immunohistochemistry.

A

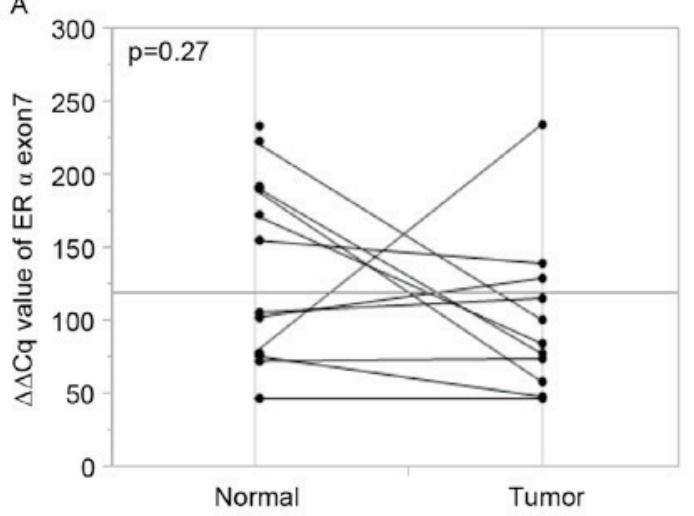

C

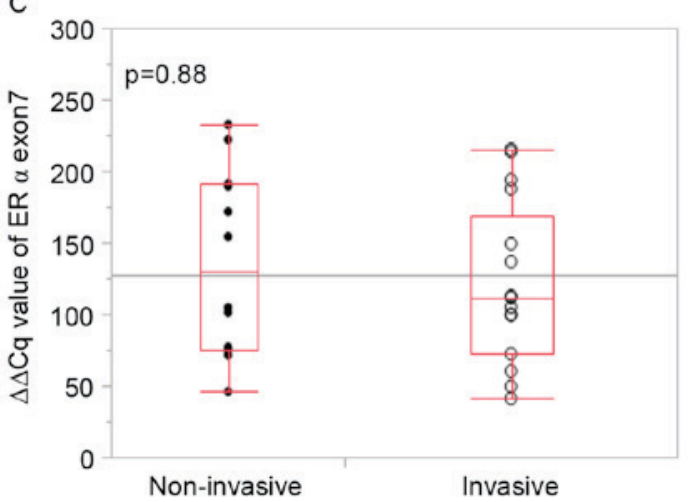

B
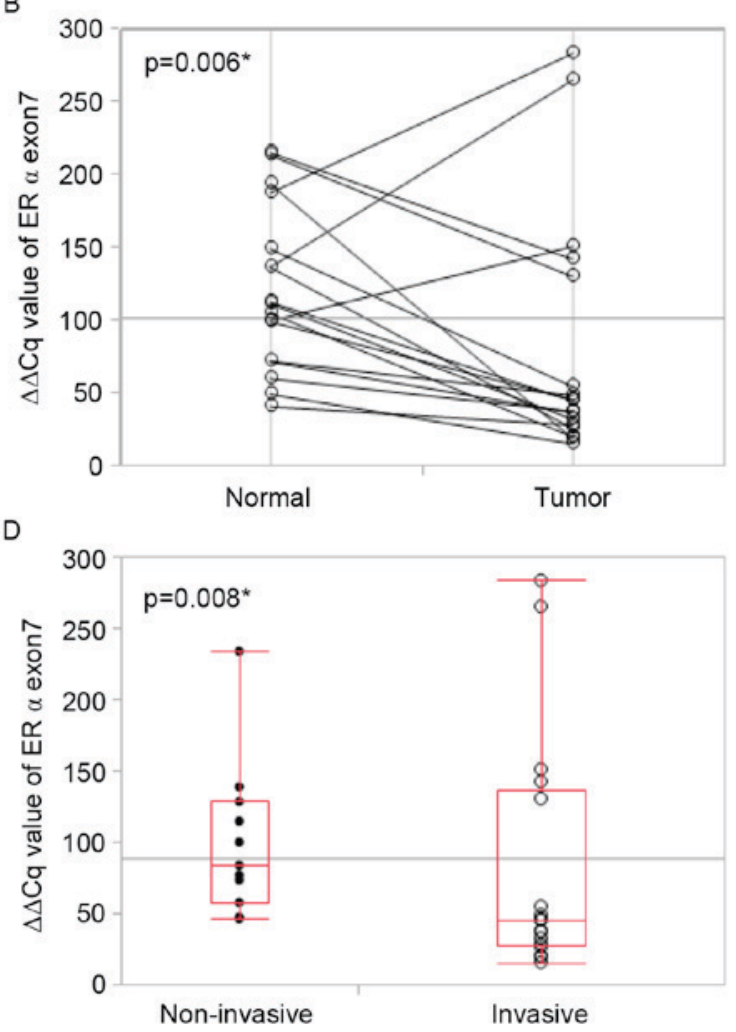

Figure 3. Association between ER $\alpha$ exon 7 expression and pathological invasiveness of smoking-independent lung adenocarcinoma. (A) Differences in ER $\alpha$ exon 7 expression between normal lung tissue and tumor tissue in non-invasive lung cancer patients as determined by reverse transcription quantitative polymerase chain reaction. (B) Differences in ER $\alpha$ exon 7 expression between normal lung tissue and tumor tissue in invasive lung cancer patients. (C) Box plot comparing ER $\alpha$ expression levels of normal tissues between non-invasive lung cancer patients and invasive lung cancer patients. (D) Box plot comparing ER $\alpha$ expression levels of tumor tissues between non-invasive lung cancer patients and invasive lung cancer patients. Black circles represent pathologically non-invasive lung cancer, and white circles represent pathologically invasive lung cancer. ER $\alpha$, estrogen receptor $\alpha$; ${ }^{*} \mathrm{P}<0.05$.

additional investigation, which may be affecting this discrepancy between studies.

There are a number of studies, which indicate that $\operatorname{ER} \alpha(9,11-13,23)$ and $\operatorname{ER} \beta$ expression $(12,14-19,21)$ can be used as markers to predict prognosis outcomes of lung cancer. Antibody selection for IHC has been discussed for this difference. The present study selected antibody (catalog no.) sc543 for the detection of ER $\alpha$ and (catalog no.) sc8943 for the detection of ER $\beta$ as these antibodies were used in several previous reports $(11,12,19,29-33)$. These two antibodies demonstrated good staining in human placenta tissues. Positive detection rates for ER $\alpha$ have been reported in previous studies $(11,12,19,29-33)$. In the present study, ER $\beta$, particularly nuclear ER $\beta$, revealed a higher detection rate compared with previous studies $(13,18,29)$. Previous studies have reported an association between nuclear ER $\beta$ expression 
A

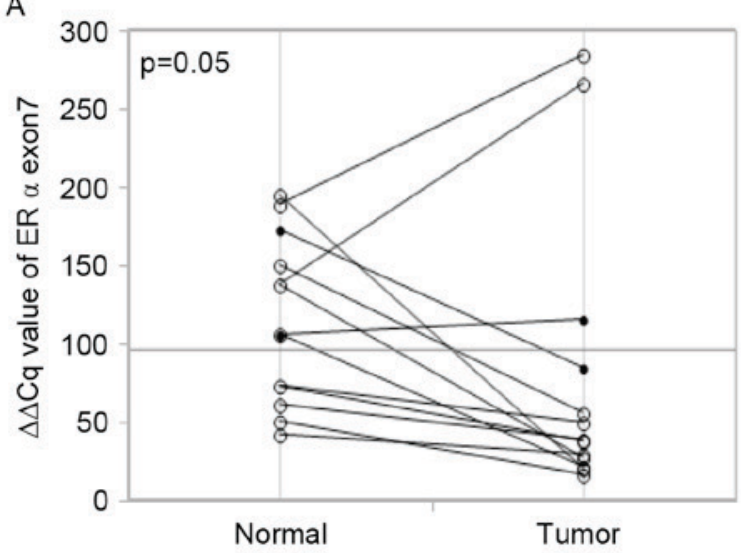

C

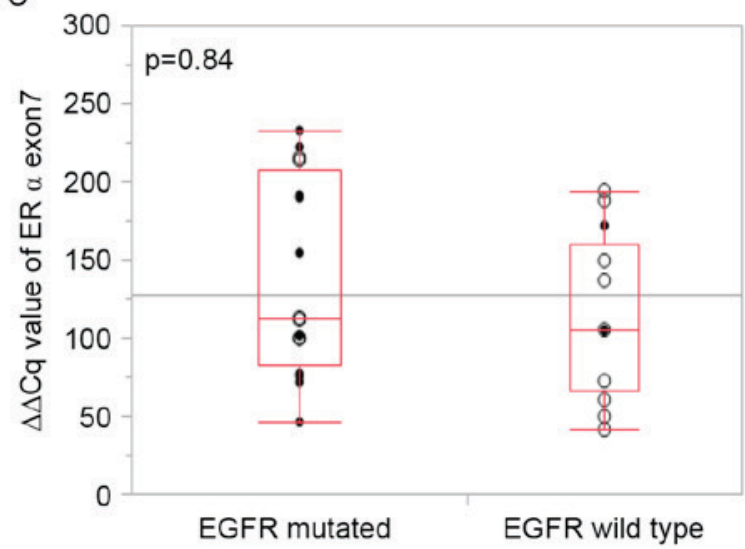

B

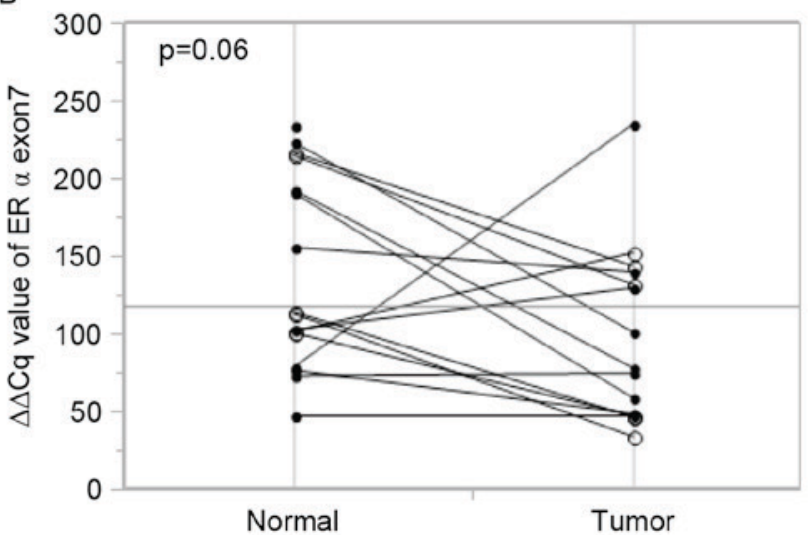

D

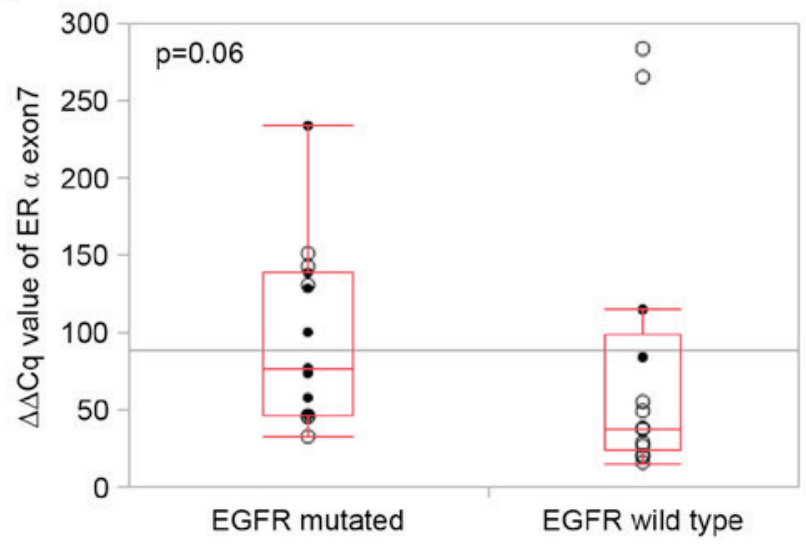

Figure 4. Association between ER $\alpha$ exon 7 expression and EGFR mutation status. (A) Differences in ER $\alpha$ exon 7 expression between normal lung tissue and tumor tissue in EGFR wild-type lung cancer patients as determined by reverse transcription quantitative polymerase chain reaction. (B) Differences in ERo exon 7 expression between normal lung tissue and tumor tissue in EGFR mutated lung cancer patients. (C) Box plot comparing ER $\alpha$ expression levels of normal tissues between EGFR wild-type lung cancer patients and EGFR mutated lung cancer patients. (D) Box plot comparing ER $\alpha$ expression levels of tumor tissues between EGFR wild-type lung cancer patients and EGFR mutated lung cancer patients. Black circles represent pathologically non-invasive lung cancer, and white circles represent pathologically invasive lung cancer. EGFR, epidermal growth factor receptor; ER $\alpha$, estrogen receptor $\alpha$.

and improved prognosis when all stages of lung cancer were compared $(13,18,29)$. This discrepancy in ER $\beta$ data may be due to the population of the present study, which consists mainly of patients with stage I lung cancer.

The present study demonstrates that ER $\alpha$ is associated with progressive pathological invasiveness, indicating worse prognosis, compared with ER $\beta$ in lung cancer. This finding is consistent with a number of previous reports $(11,12,23)$. Although the rate of $\mathrm{ER} \alpha$ positive cases was within the range of previous reports $(11,12,19,29-33)$, the present study demonstrated an improved association between ER $\alpha$ and pathological invasiveness. The present study, which focused on smoking-independent lung cancer, may contribute to the significance of previous studies. However, the size of the present study was smaller compared with previous studies investigating hormone-associated factors. A study with a larger sample size is required.

An in vitro experiment has demonstrated that a number of extra-nuclear ER $\alpha$ stained against epitope HC-20 were exon 7 splicing variants of $\mathrm{ER} \alpha$ (27). As a wide range of alternative splicing variants have been identified in lung cancer tissues (28), determining a specific splicing variant from direct sequencing would have been quite challenging, considering the limited amount of frozen specimens. The present study attempted to confirm the splicing of ER $\alpha$ exon 7 by comparing RT-qPCR results between exon 6 and exon 7. The data revealed that lower expression levels of ER $\alpha$ exon 7 correlate with extra-nuclear $\mathrm{ER} \alpha$ expression and pathological invasiveness, indicating that exon 7 splicing variants of ER $\alpha$ perform a role in acquired invasiveness in smoking-independent lung cancers.

Exon 7 splicing variants of ER $\alpha$ lack a part of the ligand binding domain, indicating a dominant-negative phenotype against estrogen signaling (27). A previous study on endometrial cancer demonstrated an improved prognosis with an increased expression of this splicing variant (34). However, the findings of the present study into lung cancer identified an association between exon 7 splicing variants of ER $\alpha$ and a more invasive type of lung cancer, which has potential for poorer prognoses. This discrepancy in findings may be due to the difference in environmental estrogen levels between the normal lung and uterus. The expression of splicing variants differs between tissues (35), indicating that splicing variants perform different roles depending on the tissue environment. Whole length ER $\alpha$ are known to move dynamically from the membrane to the nucleus, and to the membrane again. The reason why exon 7 splicing variants of ER $\alpha$ appear to accumulate in the extra-nuclear space in lung cancer tissues requires additional investigation. 
At present, sex is hypothesized to be the sole risk factor for EGFR mutation (6), which therefore implies an association between EGFR mutation and hormonal factors. The conclusions of whether there is a direct association between these 2 pathways have not yet been determined $(9,12,14,19,28)$. EGFR and ER are known to interact downstream of the proliferating cascade. A study by Garon et al (9) using human NSCLC xenografts demonstrated that an anti-estrogen drug promoted the anti-proliferative effects of an EGFR-TKI, which indicates that the ER signaling pathway is able to direct interact with the EGFR signaling pathway. The data of the present study demonstrated that patients with EGFR wild-type lung cancer are likely to express ER $\alpha$ with lower exon 7 expression, while patients with EGFR mutated lung cancer possessed a wide range of ER $\alpha$ exon 7 expression levels. The association between EGFR mutation status and lower ER $\alpha$ exon 7 expression demonstrates possible interaction between these 2 pathways.

The mechanism underlying the decrease of ER $\alpha$ exon 7 may well be involved in the acquired invasiveness of lung cancer, particularly with EGFR wild-type lung cancer. Whether the decrease in the expression of ER $\alpha$ exon 7 is the trigger, or a different trigger is inducing the splicing requires additional study. The involvement of the splicing variants accumulating in the extra-nuclear is another area which requires additional investigation.

The present study suggests an association between the expression of an exon 7 splicing variant of $\operatorname{ER} \alpha$ and pathological invasiveness in lung cancer tissues. It was also indicated that a lower expression of ER $\alpha$ exon 7 may be associated with EGFR wild-type lung cancer tissues compared with EGFR mutated lung cancer tissues. The post-translational splicing mechanism of ER $\alpha$ may be involved in the acquired invasiveness of smoking-independent lung cancer. Additional investigation with a larger sample, and in vitro experiments, are required.

\section{Acknowledgements}

The authors would like to thank Emeritus Professor Yoshitaka Fujii, Department of Oncology, Immunology and Surgery, Nagoya City University Graduate School of Medical Sciences for helpful advice and discussions regarding the manuscript. The abstract was presented at the IASLC 17th World Conference on Lung Cancer 4 December 2016-7 December 2016 in Vienna, Austria and published as abstract no. P3 01-044 in the Journal of Thoracic Oncology Vol 12: no. 1S, 2017.

\section{References}

1. World Cancer Reports 2014. http://publications.iarc.fr/ Non-Series-Publications/World-Cancer-Reports/World-CancerReport-2014. Accessed September 27, 2016.

2. U.S. National Cancer Institute and World Health Organization: The Economics of Tobacco and Tobacco Control. National Cancer Institute Tobacco Control Monograph 21. NIH Publication No. 16-CA-8029A. U.S. Department of Health and Human Services, National Institutes of Health, National Cancer Institute, Bethesda, MD; and World Health Organization, Geneva, 2016

3. Yano T, Miura N, Takenaka T, Haro A, Okazaki H, Ohba T, Kouso H, Kometani T, Shoji F and Maehara Y: Never-smoking nonsmall cell lung cancer as a separate entity: Clinicopathologic features and survival. Cancer 113: 1012-1018, 2008.

4. Subramanian J and Govindan R: Lung cancer in never smokers: A review. J Clin Oncol 25: 561-570, 2007.
5. Pao W and Girard N: New driver mutations in non-small-cell lung cancer. Lancet Oncol 12: 175-180, 2011.

6. Mitsudomi T: Molecular epidemiology of lung cancer and geographic variations with special reference to EGFR mutations. Transl Lung Cancer Res 3: 205-211, 2014.

7. Brandt B, Meyer-Staeckling S, Schmidt H, Agelopoulos K and Buerger H: Mechanisms of egfr gene transcription modulation: Relationship to cancer risk and therapy response. Clin Cancer Res 12: 7252-7260, 2006.

8. Kohno M, Okamoto T, Suda K, Shimokawa M, Kitahara H, Shimamatsu S, Konishi H, Yoshida T, Takenoyama M, Yano T and Maehara Y: Prognostic and therapeutic implications of aromatase expression in lung adenocarcinomas with EGFR mutations. Clin Cancer Res 20: 3613-3622, 2014.

9. Garon EB, Pietras RJ, Finn RS, Kamranpour N, Pitts S, Márquez-Garbán DC, Desai AJ, Dering J, Hosmer W, von Euw EM, et al: Antiestrogen fulvestrant enhances the antiproliferative effects of epidermal growth factor receptor inhibitors in human non-small-cell lung cancer. J Thorac Oncol 8: 270-278, 2013.

10. Niikawa H, Suzuki T, Miki Y, Suzuki S, Nagasaki S, Akahira J, Honma S, Evans DB, Hayashi S, Kondo T and Sasano H: Intratumoral estrogens and estrogen receptors in human non-small cell lung carcinoma. Clin Cancer Res 14: 4417-4426, 2008

11. Shimizu K, Hirami Y, Saisho S, Yukawa T, Maeda A, Yasuda K and Nakata M: Membrane-bound estrogen receptor- $\alpha$ expression and epidermal growth factor receptor mutation are associated with a poor prognosis in lung adenocarcinoma patients. World J Surg Oncol 10: 141, 2012.

12. Raso MG, Behrens C, Herynk MH, Liu S, Prudkin L, Ozburn NC, Woods DM, Tang X, Mehran RJ, Moran C, et al: Immunohistochemical expression of estrogen and progesterone receptors identifies a subset of NSCLCs and correlates with EGFR mutation. Clin Cancer Res 15: 5359-5368, 2009.

13. Rouquette I, Lauwers-Cances V, Allera C, Brouchet L, Milia J, Nicaise Y, Laurent J, Delisle MB, Favre G, Didier A and Mazières J: Characteristics of lung cancer in women: Importance of hormonal and growth factors. Lung Cancer 76: 280-285, 2012.

14. Wang Z, Li Z, Ding X, Shen Z, Liu Z, An T, Duan J, Zhong J, Wu M, Zhao J, et al: ERbeta localization influenced outcomes of EGFR-TKI treatment in NSCLC patients with EGFR mutations. Sci Rep 5: 11392, 2015.

15. Verma MK, Miki Y, Abe K, Nagasaki S, Niikawa H, Suzuki S, Kondo $\mathrm{T}$ and Sasano H: Co-expression of estrogen receptor beta and aromatase in Japanese lung cancer patients: Gender-dependent clinical outcome. Life Sci 91: 800-808, 2012.

16. Mah V, Marquez D, Alavi M, Maresh EL, Zhang L, Yoon N, Horvath S, Bagryanova L, Fishbein MC, Chia D, et al: Expression levels of estrogen receptor beta in conjunction with aromatase predict survival in non-small cell lung cancer. Lung Cancer 74: 318-325, 2011.

17. Nose N, Uramoto H, Iwata T, Hanagiri $\mathrm{T}$ and Yasumoto $\mathrm{K}$ : Expression of estrogen receptor beta predicts a clinical response and longer progression-free survival after treatment with EGFR-TKI for adenocarcinoma of the lung. Lung Cancer 71: 350-355, 2011.

18. Abe K, Miki Y, Ono K, Mori M, Kakinuma H, Kou Y, Kudo N, Koguchi M, Niikawa H, Suzuki S, et al: Highly concordant coexpression of aromatase and estrogen receptor beta in non-small cell lung cancer. Hum Pathol 41: 190-198, 2010.

19. Nose N, Sugio K, Oyama T, Nozoe T, Uramoto H, Iwata T, Onitsuka T and Yasumoto K: Association between estrogen receptor-beta expression and epidermal growth factor receptor mutation in the postoperative prognosis of adenocarcinoma of the lung. J Clin Oncol 27: 411-417, 2009.

20. Omoto Y, Kobayashi Y, Nishida K, Tsuchiya E, Eguchi H, Nakagawa K, Ishikawa Y, Yamori T, Iwase H, Fujii Y, et al: Expression, function, and clinical implications of the estrogen receptor beta in human lung cancers. Biochem Biophys Res Commun 285: 340-347, 2001.

21. Tanaka K, Shimizu K, Kakegawa S, Ohtaki Y, Nagashima T, Kaira K, Horiguchi J, Oyama T and Takeyoshi I: Prognostic significance of aromatase and estrogen receptor beta expression in EGFR wild-type lung adenocarcinoma. Am J Transl Res 8: 81-97, 2016.

22. Schwartz AG, Ray RM, Cote ML, Abrams J, Sokol RJ, Hendrix SL, Chen C, Chlebowski RT, Hubbell FA, Kooperberg $\mathrm{C}$, et al: Hormone use, reproductive history, and risk of lung cancer: The women's health initiative studies. J Thorac Oncol 10: 1004-1013, 2015 
23. Mazieres J, Rouquette I, Lepage B, Milia J, Brouchet L, Guibert N, Beau-Faller M, Validire P, Hofman P and Fouret P: Specificities of lung adenocarcinoma in women who have never smoked. J Thorac Oncol 8: 923-929, 2013.

24. International Union Against Cancer (UICC): TNM Classification of Malignant Tumours. Sobin LH, Gospodarowicz MK and Wittekind C (eds). 7th edition. Wiley-Blackwell, Oxford, 2009.

25. Travis WD, Brambilla E, Noguchi M, Nicholson AG, Geisinger KR, Yatabe Y, Beer DG, Powell CA, Riely GJ, Van Schil PE, et al: International association for the study of lung cancer/american thoracic society/european respiratory society international multidisciplinary classification of lung adenocarcinoma. J Thorac Oncol 6: 244-285, 2011.

26. Livak KJ and Schmittgen TD: Analysis of relative gene expression data using real-time quantitative PCR and the 2(-Delta Delta C(T)) Method. Methods 25: 402-408, 2001.

27. Ivanova MM, Mazhawidza W, Dougherty SM and Klinge CM: Sex differences in estrogen receptor subcellular location and activity in lung adenocarcinoma cells. Am J Respir Cell Mol Biol 42: 320-330, 2010.

28. Fasco MJ,Hurteau GJ and Spivack SD: Gender-dependent expression of alpha and beta estrogen receptors in human nontumor and tumor lung tissue. Mol Cell Endocrinol 188: 125-140, 2002.

29. Kawai H, Ishii A, Washiya K, Konno T, Kon H, Yamaya C, Ono I, Minamiya $Y$ and Ogawa J: Estrogen receptor alpha and beta are prognostic factors in non-small cell lung cancer. Clin Cancer Res 11: 5084-5089, 2005.
30. Schwartz AG, Prysak GM, Murphy V, Lonardo F, Pass H, Schwartz J and Brooks S: Nuclear estrogen receptor beta in lung cancer: Expression and survival differences by sex. Clin Cancer Res 11: 7280-7287, 2005.

31. Márquez-Garbán DC, Chen HW, Fishbein MC, Goodglick L and Pietras RJ: Estrogen receptor signaling pathways in human non-small cell lung cancer. Steroids 72: 135-143, 2007.

32. Stabile LP, Dacic S, Land SR, Lenzner DE, Dhir R, Acquafondata M, Landreneau RJ, Grandis JR and Siegfried JM: Combined analysis of estrogen receptor beta-1 and progesterone receptor expression identifies lung cancer patients with poor outcome. Clin Cancer Res 17: 154-164, 2011.

33. Sun HB, Zheng Y, Ou W, Fang Q, Li P, Ye X, Zhang BB, Yang H and Wang SY: Association between hormone receptor expression and epidermal growth factor receptor mutation in patients operated on for non-small cell lung cancer. Ann Thorac Surg 91: 1562-1567, 2011.

34. Hirschfeld M, Ouyang YQ, Jaeger M, Erbes T, Orlowska-Volk M, Zur Hausen A and Stickeler E: HNRNP G and HTRA2-BETA1 regulate estrogen receptor alpha expression with potential impact on endometrial cancer. BMC Cancer 15: 86, 2015.

35. Chen M and Manley JL: Mechanisms of alternative splicing regulation: Insights from molecular and genomics approaches. Nat Rev Mol Cell Biol 10: 741-754, 2009. 